Vol 2. No 2. Agustus 2018

ISSN 2580-5029

\title{
Dogs (Canis lupus familiaris) As Virus Carrier in Indonesia
}

Moch. Irfan Hadi ${ }^{*}$, Muhammad Yusuf Alamudi ${ }^{2}$, Hanik Faizah', Eko Teguh Pibadi', Tatag Bagus Putra Prakarsa ${ }^{1}$, Eva agustina ${ }^{1}$, Misbakhul munir ${ }^{1}$, Muhamad Ratodi', Mei lina Fitri Kumalasari ${ }^{1}$, Sri Hidayati ${ }^{1}$

1Universitas Islam Negeri Sunan Ampel Surabaya, Indonesia

${ }^{2}$ Prof Nidom Foundation, Surabaya, Indonesia

*m_i_h@uinsby.ac.id

\section{ABSTRACT}

A Virus is an individual that cannot be described as an animal or a plant. If animals and plants contain two nucleic acids (DNA and RNA), on the contrary, the virus only has one of them. These nucleic acids can stimulate a complete virus replication cycle. The virus can only replicate and live on a living host if the host is finally dead, then the virus will move on the cells that are still alive. The virus has genetic material which is a protective protein coat called a capsid. Viruses can infect various varieties of organisms, both eukaryotes (animals, plants, protists, and fungi) and prokaryotes (bacteria and archaea). The Virus infects bacteria known as bacteriophage (phage). The Virus can cause serious diseases for humans such as AIDS, HIV, rabies, etc. Dogs belonging to Canidae family are the sibling of wolves, foxes and raccoon dogs. Among all members of Canidae, dogs have the most closely related to wolves which are the ancestors of dogs. The Canidae family generally has a small elongated body, sharp ear and muzzle, sharp smelling, can run fast and can swim. Dogs are human best friends. While taking care of the dogs, they can be attacked by various diseases. The closeness of the relationship between humans and dogs raises the potential for disease transmission, especially zoonosis and pandemics viruses.

Keywords: Canis lupus familiaris, carrier, influenza, virus

\section{INTRODUCTION}

The word virus comes from Latin referring to poison. The history of the discovery of the virus began in 1883 by Adolf Mayer, a German scientist. He studied the causes of mosaic disease in tobacco that caused tobacco growth to be dwarfed, and the leaves are yellow. Mayer discovered that the mosaic disease was transmitted to other tobacco plants when he sprayed diseased tobacco leaf extracts to healthy plants. Mayer concluded that the disease was caused by tiny bacteria. These bacteria could not be seen using a light microscope (Ahmed et al., 2012). In 1892 a Russian scientist named Dmitri Iwanowski filtered out tobacco leaf 
extracts with a designed sieve so that bacteria did not escape and could also obtain the leaf tobacco filtrate. Once the filtrate was sprayed on healthy tobacco plants, then the plant was infected with the mosaic disease. So he concluded that the cause of this mosaic disease was a smaller organism than bacteria because it could pass through filtration. In 1898 a scientist named Martinus W. Beirejerinck made the observation same with Iwanowski. He argued that the infecting agent was as a filterable virus because the agent could escape the bacterial filtration and could not be observed by a light microscope. The term filterable virus then shortened to a virus. Iwanowski and beijerick were named as the inventor of virus (Borodavka et al., 2013, 2012).

The virus is composed of nucleic acids, i.e., deoxyribonucleic acid (DNA) or ribonucleic acid (RNA) wrapped by a protein envelope called capsid. Viruses can be classified according to their nucleic acid content. In RNA viruses, single-stranded (e.g., picornaviruses that cause polio and influenza) or multiple strands (e.g., rotaviruses that cause diarrhea); as well as DNA virus (e.g., single-stranded on circovirus and parvovirus, double-stranded on adenovirus, herpesvirus, and poxvirus) (Lefkowitz et al., 2017).

The RNA virus consists of three main types: a positive-stranded (+) RNA virus, whose genome acts as mRNA in a host cell and acts as a template for intermediate of minus (-) strand RNA; a negative-stranded (-) RNA virus that cannot directly act as mRNA, but as a template for synthesis of mRNA through virion transcriptase; and retroviruses, which (+) strand and can act as mRNAs, but at the times the infection immediately acts as a double-stranded DNA synthesis template (soon integrates into the host chromosome) via an encrypted or encoded transcriptase. Each human immunedeficiency virus (HIV) is a part of lentivirus subgroup of the RNA retrovirus group. This virus is the cause of AIDS in humans infecting every cell that expresses the surface marker of CD4 cells, such as a mature T-cell builder (Dai et al., 2017; Hall et al., 2011).

Dogs (Canis lupus familiaris) is a carnivorous mammal that has been domesticated from wolves from 10,000 to 15,000 years ago and has been growing up to now that has reached hundreds of races of all kinds. C.l. familiaris is endowed with advantages 
in the sense of smell, hearing, and sight. The closeness of the behavior pattern of C.l.familiaris with humans makes C. l.familiaris can be trained, invited to play, live with humans, and be socialized with humans and other C.l.familiaris. Some of the reasons people keep C.l.familiaris are like friends, for fun, prestige, and additional activity (Call et al., 2003).

\section{Canis lupus familiaris as Virus Carrier}

\section{in Indonesia}

\section{Virus Structure}

A complete viral particle is called virion. It was composed of nucleic acids (genomes), and coats called capsids (composed of protein subunits called capsomere). Capsomere as proteins encoded by viral genomes is a structural protein. It is due to the capsomers participation in building the structure of virus particles. The viral genome also encodes some essential enzymes (which are not owned by the host) for replication (Erickson et al., 2012).

These proteins or enzymes are not part of the virion, so they are called nonstructural proteins. In some viruses, the capsid is enclosed by a lipid-containing envelop. This envelop comes from the host's plasma membrane and is acquired by the virus when the virus escapes from the host cell by budding. In some enveloped viruses there are many spikes in the form of protrusions that are used for attachment to host cells (Novoa et al., 2005).

Unlike living organisms, based on their capsid architecture, viruses can be classified into polyhedral (or icosahedral) viruses, helical viruses, and complex viruses. Based on the genome, viruses can be classified into doublestranded DNA virus (dsDNA), singlestranded DNA virus (ssDNA), doublestranded RNA virus (dsRNA), and single-stranded RNA virus (ssRNA). There are two types of ssRNA virus, the first is the sense strand (or positive sense or positive-stranded), because the genome (RNA) acts as mRNA; the second is the antisense strand (or negative sense or negative-stranded), because the genome functions as a template to make mRNA (+ strand). The viral genome also has some conformations: linear, circular, continuous, or segmented (Netherton et al., 2007; Stockley et al., 2013; Wileman, 2007).

\section{Virus Replication}

Virus replication consists of 6 stages (Netherton et al., 2007; Stockley et al., 2013) : (1) Adhesion (= attachment, adsorption). At this stage, 
the viral receptor-binding protein binds specifically to the receptor on the host cell surface. (2) Penetration (= internalization). There are three types of mechanisms for penetration: fusion, endocytosis (viropexis), and translocation. (3) Uncoating. Viral nucleic acids are separate from their coat proteins. (4) Biosynthesis. This stage consists of the production of structural proteins of viruses and enzymes as well as viral genome replication. In general, this biosynthesis process begins with the making of mRNA, except in the dsRNA and + sRNA viruses (since the genome itself functions as mRNA) and retroviruses (RNA viruses that have reverse transcriptase enzymes that immediately transcribe the viral genome making cDNAs integrated into chromosomes host). For the manufacture of mRNA, DNA viruses use the host DNA polymerase, whereas single strandedRNA viruses use RNA-dependent, RNA polymerase which it carries alone. This RNA messenger will be translated to make the structural proteins and enzymes needed by the virus. RNA viral replication occurs in the cytoplasm (except retroviruses) using RNAdependent RNA polymerase, whereas DNA viral replication occurs in the nucleus (except poxviruses) using host polymerase DNA. (5) Maturation (= assembly). Begin with the construction of protein of capsid followed by packaging of the viral genome. (6) Release (release). The enveloped virus that escapes through the budding (the plasma membrane of the host cell forms the envelop virus), while the nonenveloped virus passes through the plasma cell membrane rupture of the host cell (dead host cell).

According to Indonesian Law (UU No.6 of 1967), the definition of zoonosis is a disease that can be transmitted from animal to human and vice versa or also called Anthropozoonosis. Similarly, in the UU No.18 of 2009 about animal husbandry and health, in place of the UU No. 6 of 1967 stated that zoonotic disease is a disease that can be transmitted from animals to humans and vice versa. While based on WHO, the definition of zoonosis is a disease or infection that is naturally transmitted from vertebrate animals to humans. Zoonosis, according to the World Organization for Animal Health (OIE Office Internationale Epizooticae), is a disease that can naturally spread among vertebrate animals and human. Diseases classified in zoonosis with the spread of the disease spread throughout the 
world and often found in Indonesia are such as anthrax, rabies, leptospirosis, brucellosis, toxoplasmosis, tuberculosis, salmonellosis, avian influenza, and others. From some of the definitions above, it can be concluded that zoonosis is a transmitted infection between vertebrate animals and human, zoonosis is a disease that can naturally transmit from animals to humans and vice versa (Soejoedono, 2004; Suharsono, 2002; Widiasih, 2012; Wileman, 2007).

C.l.familiaris is one of the people's favorite pet because this animal has a high level of intelligence and has a true nature, so that becomes part of the community life as a guard and friends in the family. Therefore it is always treated, and its health is controlled. Parvovirus, coronavirus, and rotavirus are known to cause viral enteritis and diarrhea in C.l.familiaris. Parvovirus in C.l.familiaris often attacks at all ages and all types of dogs. In general, the virus attacks puppies aged 2-6 months. Transmission of the disease occurs directly through direct contact with sick dogs, whereas indirect contamination can be through contaminated faces (Nichols and Smith, 2002; Schmutz and Berryere, 2007). The viruses infected in C.l.familiaris and potentially contagious in humans can be seen in table 1 .
Table 1. The Viruses that Infected in C.l.familiaris and Potentially Contagious in Humans

\begin{tabular}{|c|c|}
\hline Virus names & Virus types \\
\hline Rabies & $\begin{array}{l}\text { Negative stranded } \\
\text { RNA(Cheong et al., } \\
\text { 2014; World Health } \\
\text { Organization, 2008) }\end{array}$ \\
\hline Parvovirus & $\begin{array}{l}\text { Single stranded } \\
\text { DNA(Ahmed et al., } \\
\text { 2012; Aldaz et al., } \\
\text { 2013; Allison et al., } \\
\text { 2011) }\end{array}$ \\
\hline $\begin{array}{l}\text { Hepatitis Canine } \\
\text { adenovirus (CAV) } \\
\text { type } 1\end{array}$ & $\begin{array}{l}\text { Double stranded DNA } \\
\text { (Balboni et al., 2013) }\end{array}$ \\
\hline $\begin{array}{l}\text { Canine distemper } \\
\text { (paramixovirus) }\end{array}$ & $\begin{array}{l}\text { Negative stranded RNA } \\
\text { (Carvalho et al., 2012; } \\
\text { Di Francesco et al., } \\
\text { 2012) }\end{array}$ \\
\hline $\begin{array}{l}\text { Parainfluenza } \\
\text { virus }\end{array}$ & $\begin{array}{l}\text { Negative stranded RNA } \\
\text { (Call et al., 2003; } \\
\text { Kaczorek et al., 2017) }\end{array}$ \\
\hline Rotavirus & $\begin{array}{l}\text { Double stranded RNA } \\
\text { (Lefkowitz et al., 2017) }\end{array}$ \\
\hline $\begin{array}{l}\text { Canine adenovirus } \\
\text { (CAV) type } 2 \\
\text { (infectious canine } \\
\text { laryngotracheitis) }\end{array}$ & $\begin{array}{l}\text { Double stranded DNA } \\
\text { (Balboni et al., 2013) }\end{array}$ \\
\hline Circovirus & $\begin{array}{l}\text { Single stranded DNA } \\
\text { (Cheong et al., 2014) }\end{array}$ \\
\hline $\begin{array}{l}\text { Equine influenza } \\
\text { A (H3N8) }\end{array}$ & $\begin{array}{l}\text { Negative-strand } \\
\text { RNA(Jirjis et al., 2010; } \\
\text { Pecoraro et al., 2013) }\end{array}$ \\
\hline $\begin{array}{l}\text { Seasonal } \\
\text { influenza (H3N2) }\end{array}$ & $\begin{array}{l}\text { Negative-strand } \\
\text { RNA(Kapoor et al., } \\
\text { 2012) }\end{array}$ \\
\hline $\begin{array}{l}\text { Avian influenza } \\
\text { (H5N1) } \\
\text { Calicivirus }\end{array}$ & $\begin{array}{l}\text { Negative-strand RNA } \\
\text { (Stockley et al., 2013) } \\
\text { Single stranded } \\
\text { positive RNA } \\
\text { (Mosallanejad et al., } \\
\text { 2015) }\end{array}$ \\
\hline Picornavirus & $\begin{array}{l}\text { Single stranded } \\
\text { positive RNA (Schmutz } \\
\text { and Berryere, 2007) }\end{array}$ \\
\hline $\begin{array}{l}\text { Canine } \\
\text { pneumovirus }\end{array}$ & $\begin{array}{l}\text { Single stranded } \\
\text { negative RNA (Ellis and } \\
\text { Krakowka, 2012; } \\
\text { Pecoraro et al., 2013) }\end{array}$ \\
\hline $\begin{array}{l}\text { Pantropic canine } \\
\text { coronavirus }\end{array}$ & $\begin{array}{l}\text { Single stranded } \\
\text { positive RNA(Kaczorek } \\
\text { et al., 2017; }\end{array}$ \\
\hline
\end{tabular}




\begin{tabular}{ll}
\hline & Mosallanejad et al., \\
& 2015) \\
\hline Canine bocavirus & Single stranded \\
& DNA(Kapoor et al., \\
& 2012) \\
\hline Canine & Single stranded \\
hepacivirus & positive RNA(Bexfield \\
& et al., 2014) \\
\hline
\end{tabular}

Source: Secondary Data, 2018

\section{CONCLUSION}

C. l.familiaris is one of the carriers of infectious diseases, primarily the zoonotic in Indonesia. It is because Indonesia is a region that has a tropical climate and still has contagious diseases with a high prevalence and average incidence. More studies of C. I.familiaris on various infectious agents from other microorganisms such as bacteria, fungi, parasites, helminths and protozoa are needed. Also, the study of receptors on C. l.familiaris against various infectious agents and diagnostic technologies are open to the development of science and technology.

\section{REFERENCES}

Ahmed, A.F., Odeisho, S.M., Karim, Z.A., 2012. Detection of Canine Parvovirus in Baghdad City by PCR Technique. The Iraqi Journal of Veterinary Medicine. 36, 95-98.

Aldaz, J., García-Díaz, J., Calleros, L., Sosa, K., Iraola, G., Marandino, A., Hernández, M., Panzera, Y., Pérez, R., 2013. High Local Genetic Diversity of Canine parvovirus from Ecuador. Veterinary Microbiology. 166, 214-219.

Allison, A.B., Harbison, C.E., Pagan, I., Stucker, K.M., Kaelber, J.T., Brown, J.D., Ruder, M.G., Keel, M.K., Dubovi, E.J., Holmes, E.C., 2011. The Role of Multiple Hosts in the Cross-species Transmission and Emergence of a Pandemic Parvovirus. Journal of Virology. JVI06187.

Balboni, A., Verin, R., Morandi, F., Poli, A., Prosperi, S., Battilani, M., 2013. Molecular epidemiology of Canine adenovirus type 1 and type 2 in Free-ranging Red Foxes (Vulpes vulpes) in Italy. Veterinary Microbiology. 162, 551-557.

Bexfield, N., Watson, P., Heaney, J., Heeney, J., Tiley, L., 2014. Canine hepacivirus is not Associated with Chronic Liver Disease in Dogs. Journal of Viral Hepatitis. 21, 223228.

Borodavka, A., Tuma, R., Stockley, P.G., 2013. A Two-stage mechanism of viral RNA Compaction Revealed by Single Molecule Fluorescence. RNA Biology. 10, 481-489.

Borodavka, A., Tuma, R., Stockley, P.G., 2012. Evidence that Viral RNAs have Evolved for Efficient, Twostage Packaging. Proceedings of the National Academy of Sciences. 109, 15769-15774.

Call, J., Bräuer, J., Kaminski, J., Tomasello, M., 2003. Domestic Dogs (Canis familiaris) are sensitive to the Attentional State of Humans. Journal of Comparative Psychology. 117, 257. 
Carvalho, O.V., Botelho, C.V., Ferreira, C.G.T., Scherer, P.O., SoaresMartins, J.A.P., Almeida, M.R., Silva Júnior,A, 2012. Immunopathogenic and Neurological Mechanisms of Canine distemper virus. Advances in Virology. 2012.

Cheong, Y., Kim, B., Lee, K.J., Park, D., Kim, S., Kim, H., Park, E., Lee, H., Bae, C., Oh, C., 2014. Strategic Model of National Rabies Control in Korea. Clinical and Experimental Vaccine Research. 3, 78-90.

Dai, X., Li, Z., Lai, M., Shu, S., Du, Y., Zhou, Z.H., Sun, R., 2017. In-situ Structures of the Genome and Genome-delivery Apparatus in a Single-stranded RNA Virus. Nature $541,112$.

Di Francesco, C.E., Di Francesco, D., Di Martino, B., Speranza, R., Santori, D., Boari, A., Marsilio, F., 2012. Detection by Hemi-nested Reverse Transcription Polymerase Chain Reaction and Genetic Characterization of Wild Type Strains of Canine distemper virus in Suspected Infected Dogs. Journal of Veterinary Diagnostic Investigation. 24, 107-115.

Ellis, J.A., Krakowka, G.S., 2012. A review of Canine parainfluenza virus Infection in dogs. Journal of the American Veterinary Medical Association. 240, 273-284.

Erickson, K.D., Bouchet-Marquis, C., Heiser, K., Szomolanyi-Tsuda, E., Mishra, R., Lamothe, B., Hoenger, A., Garcea, R.L., 2012. Virion Assembly Factories in the Nucleus of Polyomavirus-infected Cells. PLoS Pathogens. 8, e1002630.
Hall, A.M., Hendry, B.M., Nitsch, D., Connolly, J.O., 2011. Tenofovirassociated Kidney Toxicity in HIVinfected Patients: a Review of the Evidence. American Journal of Kidney Diseases. 57, 773-780.

Jirjis, F.F., Deshpande, M.S., Tubbs, A.L., Jayappa, H., Lakshmanan, N., Wasmoen, T.L, 2010. Transmission of Canine influenza virus (H3N8) among Susceptible Dogs. Veterinary Microbiology. 144, 303309.

Kaczorek, E., Schulz, P., Małaczewska, J., Wójcik, R., Siwicki, A.K., Stopyra, A., Lew-Kojrys, S., Pomianowski, A., Hryniewicka, K., MikulskaSkupień, E., 2017. Prevalence of Respiratory Pathogens Detected in Dogs with Kennel Cough in Poland. Acta Veterinaria Brno. 85, 329336.

Kapoor, A., Mehta, N., Dubovi, E.J., Simmonds, P., Govindasamy, L., Medina, J.L., Street, C., Shields, S., Lipkin, W.I., 2012. Characterization of Novel canine bocaviruses and their Association with Respiratory Disease. Journal of General Virology. 93, 341-346.

Lefkowitz, E.J., Dempsey, D.M., Hendrickson, R.C., Orton, R.J., Siddell, S.G., Smith, D.B., 2017. Virus Taxonomy: the Database of the International Committee on Taxonomy of Viruses (ICTV). Nucleic Acids Research. 46, D708D717.

Mosallanejad, B., Shapouri, M.R.S., Avizeh, R., Pourmahdi, M., 2015. Antigenic detection of Canine rotavirus Group A in Diarrheic Dogs in Ahvaz District, 
Southwestern Iran. Comparative Clinical Pathology. 24, 899-902.

Netherton, C., Moffat, K., Brooks, E., Wileman, T., 2007. A Guide to Viral Inclusions, Membrane Rearrangements, Factories, and Viroplasm Produced during Virus Replication. Advances in Virus Research. 70, 101-182.

Nichols, R., Smith, H., 2002. Parasites: Cryptosporidium, Giardia and Cyclospora as Foodborne Pathogens. CRC Press, Boca Raton, Florida 453-478.

Novoa, R.R., Calderita, G., Arranz, R., Fontana, J., Granzow, H., Risco, C., 2005. Virus Factories: Associations of Cell Organelles for Viral Replication and Morphogenesis. Biology of the Cell. 97, 147-172.

Pecoraro, H.L., Spindel, M.E., Bennett, S., Lunn, K.F., Landolt, G.A., 2013. Evaluation of Virus Isolation, Onestep Real-time Reverse Transcription Polymerase Chain Reaction Assay, and Two Rapid Influenza Diagnostic Tests for Detecting Canine influenza A virus H3N8 Shedding in Dogs. Journal of Veterinary Diagnostic Investigation $25,402-406$.

Schmutz, S., Berryere, T., 2007. Genes Affecting Coat Colour and Pattern in Domestic Dogs: A Review. Animal Genetics. 38, 539-549.

Soejoedono, R.R., 2004. Zoonosis. Laboratorium Kesmavet, Departemen Penyakit Hewan dan Kesmavet, Fakultas Kedokteran Hewan Institut Pertanian Bogor.

Stockley, P.G., Twarock, R., Bakker, S.E., Barker, A.M., Borodavka, A.,
Dykeman, E., Ford, R.J., Pearson, A.R., Phillips, S.E., Ranson, N.A., 2013. Packaging Signals in SingleStranded RNA Viruses: Nature's Alternative to Purely Electrostatic Assembly Mechanism. Journal of Biological Physics. 39, 277-287.

Suharsono, 2002. Zoonosis Penyakit Menular dari Hewan ke Manusia. Penerbit Kanisius. Yogyakarta.

Widiasih, D.A., 2012. Epidemiologi Zoonosis di Indonesia.

Wileman, T., 2007. Aggresomes and Pericentriolar Sites of Virus Assembly: Cellular Defense or Viral Design? Annu. Rev. Microbiol. $61,149-167$.

World Health Organization, 2008. A Neglected Zoonotic Disease. WHO Expert Consultation. Rabies. Geneva, Switzerland. 